\section{The Farmer, the Fairies, and the Computers}

\begin{abstract}
Neville Holmes, University of Tasmania
\end{abstract}

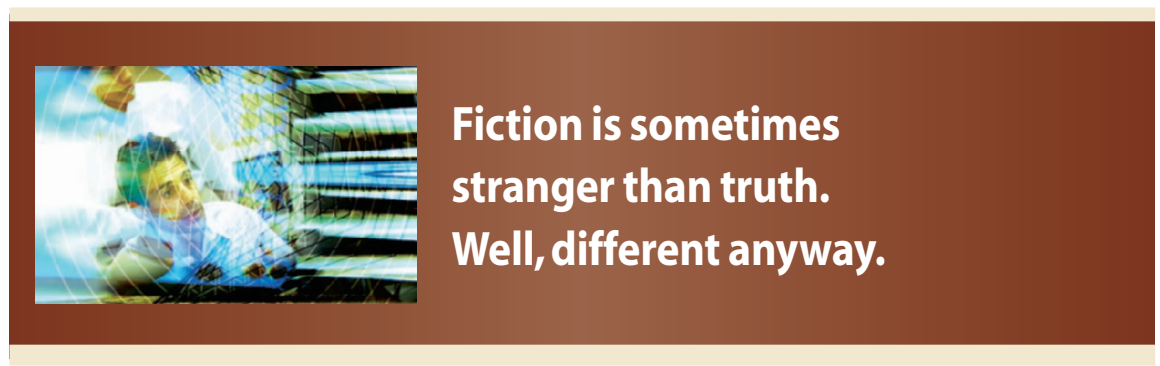

( ne fairly persistent aspect of The Profession has been an understandably natural seriousness when the focus is on matters technical and professional.

Perhaps being serious so much of the time is a mistake. When Computer published Simone Santini's delightful essay, "We are sorry to inform you ...", (Dec. 2005, pp. 128, 126-127), the early e-mail from readers congratulated him on having unearthed these important reviews. Maybe they were pulling his leg, and if so, then obviously they greatly appreciated his humor. A later e-mail more pointedly commented on the improvement a bit of humor made to the column.

A temporary substitution of style, some leaven of levity, seems worth trying again, so let's have a fairy tale.

Fairy tales are works of extreme fiction, but there will be a moral.

\section{THE FARMER}

Once upon a time there was a boy called Oldham who lived on a dairy farm, milking cows, feeding pigs, breeding ferrets, catching rabbits, riding horses, collecting eggs, cutting bracken, pitchforking hay, avoiding snakes, and wandering around the hills with a dog at his heels. However, the lure of the big city was too much. Nothing much ever happened in the countryside, while the city seemed dense with people and events.

So Oldham went to school in the big city, leaving the grass for the asphalt, and eventually became a computing professional. But he remained a farmer at heart, or at least a country boy.

When the time came for him to retire, the call of the hills and the trees sounded loudly. He took a job teaching about computers in a small provincial city. To be among the hills, trees, and birds, Oldham and his wife chose to live in the countryside, only 20 minutes away by car from his teaching job.

\section{THE GODS}

Living once again in the countryside seemed quite wonderful, except for one or two problems. The mail delivery, for example.
Oldham's house sat a little way from the roadside letter box, so whenever a registered letter or some other special item arrived, the mail elf would leave a card in the mailbox. This had to be taken to a mail grotto, not in the city but a half-hour drive in the opposite direction. Being of a professional mind, Oldham promptly solved this problem by renting a mail grotto private box near his workplace. But this was only a minor irk, and life went on serenely.

After a few years, the gods in far Valhalla began making decisions that would greatly affect ordinary life in the backblocks. They had grown tired of looking after the world outside Valhalla and rather liked the idea that, if they stopped exerting control over what went on, economic processes would ensure by themselves that the best of all possible worlds came about. So, among other similar measures, the gods decided to split the Message Ministry between the elves who looked after the mail and the fairies who looked after the telephone system.

Most people considered mail technologically dull and financially unattractive, so the elves were simply split off without any expectation they would flourish. On the other hand, the fairies' telephone system monopoly, coupled with the expected bonanza from digital networking and mobile telephony, looked promising. But there were protests, so the gods invited fauns from distant parts to compete with the fairies and stop them from exploiting their wired telephone system monopoly.

Oldham and his wife didn't understand how the fauns could compete with the fairies when the fairies owned all the wires. But, being told they could opt to get their long-distance calls from the fauns in some mysterious way, they decided to do so. The strange thing was that, whereas there seemed to be plenty of fairies around the Oldhams' region, the fauns all were located far away. So they got the gnomes who looked after their money to have their computer Continued on page 110 
automatically pay the monthly faun bills for them.

\section{THE FAIRIES}

Time passed, the Oldhams grew older, and so did their car. Fearful that their car would break down when one of them drove it to or from their nearby city, or that one of them would become ill when the other wasn't home, they became attracted to the idea of having mobile phones.

The nearby city had a sprites' grotto where mobile telephones and other electronic devices were sold, and where the Oldhams' had made friends with one of the sprites.

When they went to the grotto to buy their mobile telephones, the Oldhams became quite bewildered. In the first place, there were not only two different basic technologies to choose between, but also a multitude of different mobile telephone brands and models. They overcame this difficulty merely by taking the advice of the friendly sprite who was looking after them. But then they faced a multitude of plans and options from various suppliers of mobile-telephone communication services.

Despairing of understanding the differences enough to make a rational choice, the Oldhams asked if the fairies could simply supply the services and add the charges to the Oldhams' monthly landline telephone bill. Yes, the sprite told them, the fairies did have a computerized Amalgamated Account Scheme, but the sprites could not arrange for the Oldhams to use it, so they would have to take one of the other plans temporarily.

The Oldhams liked the AAS's simplicity and were told they would have to ring up the fairies and arrange it when they got home. The good news was that they would get a large credit to their account from the fairies for each mobile phone when they shifted from the other plan.

Unfortunately, it took several days to get through to the fairies because they had a computer answering their own telephones. Then it took several days more before the Oldhams found enough patience to get through the sequence of queues. Successful at last, they tried to use their mobile phones.

Unhappily, the several days' delay had dimmed their recollection of the demonstration the sprite had given them. For what seemed to be good reasons at the time, they had chosen different brands. This meant that they had two different manuals, neither of which was much help. Although the words were English, the sentences weren't.

\section{A lengthy interaction led to Oldham being told the missing credit would appear on the next account.}

The phones were both made by satyrs living in distant lands, so the Oldhams inferred that the satyrs had written the manuals in their own language and used a computer to translate them into English. After much experimenting, the Oldhams were able to actually make and answer phone calls, but the many other features remained a mystery.

\section{THE COMPUTERS}

When the monthly bill from the fairies' computers came, there was only one of the two credits the Oldhams expected. That was when the trouble started.

Ringing up the fairies proved fruitless. Getting to an operator who entered all the account details into his computer only led to the slightly surprised remark that it was an AAS account so he would have to switch Oldham to another operator. Unfortunately, the queue for the AAS handler seemed to be indefinitely long for several days running, so Oldham eventually drove into town, where the fairies also had a grotto.

The grotto had lots of pleasant helpful fairies and a row of computers hooked up to their network. A rather lengthy interaction between the com- puter and one of the fairies led to Oldham being told that the missing credit would appear on the next account.

Probably it was only a coincidence, but the following day, a fairy named Dagobert rang up the Oldhams to assure them that the fairies' computer had recorded their complaint about their service being cut off and that he was about to come out and look into the problem.

Oldham assured the fairy that no complaint had been made and that their talking on the phone was prima facie evidence that the service was still connected. Although Dagobert seemed to accept this, apparently the computer wouldn't, as there was a succession of calls from increasingly senior fairies until it was discovered that new people moving into a neighboring house had given the fairies' computer the Oldhams' residential address as theirs.

There were two strange consequences at the end of the month. First, there was a minatory letter from the fauns' computer complaining that their bill had not been paid. Several phone calls later, the gnomes who were supposed to be paying these bills revealed that the authority for them to pay had been cancelled-by whom they could not say. Their computer held no details. Second, and it seemed significantly related to the first, two separate bills turned up from the fairies' computer. The first bill came through the private box and was for the very few mobile phone calls the Oldhams had made, mostly for practice. The second bill was for the landline calls and turned up in the roadside letterbox mixed up with the rural newsheets and the junk mail.

The phone proving fruitless again, Oldham went into town, where a very helpful fairy, though greatly puzzled by his tale, tracked various things down on the computer, asked numerous questions, and eventually announced that he had cleared up the matter.

Sadly, next month's bills repeated the preceding month's story. Also, the gnomes had to be asked again to 
resume paying the fauns. Back in town, another helpful fairy could find no trace of the previous month's negotiations on their main computer, but assured Oldham that the changes would stick this time. And they did, although the gnomes had to be authorized again.

\section{HAPPILY EVER AFTER}

A few months later, the Oldhams prepared to leave for a long trip, so first they visited the fairies in town. Asking for their mobile phone services to be stopped while they were away, they were told that a hefty cancellation fee meant that it would be cheaper for them just to let the agreement run out. As they wished to keep their landline, or, more particularly, the phone number that went with it, the Oldhams arranged for the gnomes to also pay their monthly bills from the fairies' computer automatically.
When they returned from their trip, the Oldhams discovered that their mobile phone services had been automatically renewed by the fairies' computer, despite a complete absence of any device use, and that the gnomes' computer had been just as regularly paying up.

Being rather annoyed by this, Oldham went back to town, confronted the fairies, and told them (truthfully) that not only had he and his wife not been using their mobile phones, but (untruthfully) that they had thrown both the devices away and (truthfully) they didn't intend to buy replacements.

The fairies, quite a few of whom had gathered around to try to placate Oldham, were quite understanding, and one went to the computer and successfully arranged a refund, although this also took a few phone calls to get the required high-level authorization.
The Oldhams have ever since lived quite happily without mobile phones, although they do make sure their car is regularly maintained. They have even started to rather enjoy getting a notice in their roadside letter box every month from the fairies' computer telling them that their account is one cent in credit. You see, inflation has long ago caused their gods to stop issuing one- and two-cent coins.

$\mathbf{T}$ he moral? Don't expect understanding from a computer. Try the fairies instead.

Neville Holmes is an honorary research associate at the University of Tasmania's School of Computing. Contact him at neville.holmes@utas.edu.au.Details of citations in this essay, and links to further material, are at www.comp.utas. edu.au/users/nholmes/prfsn.
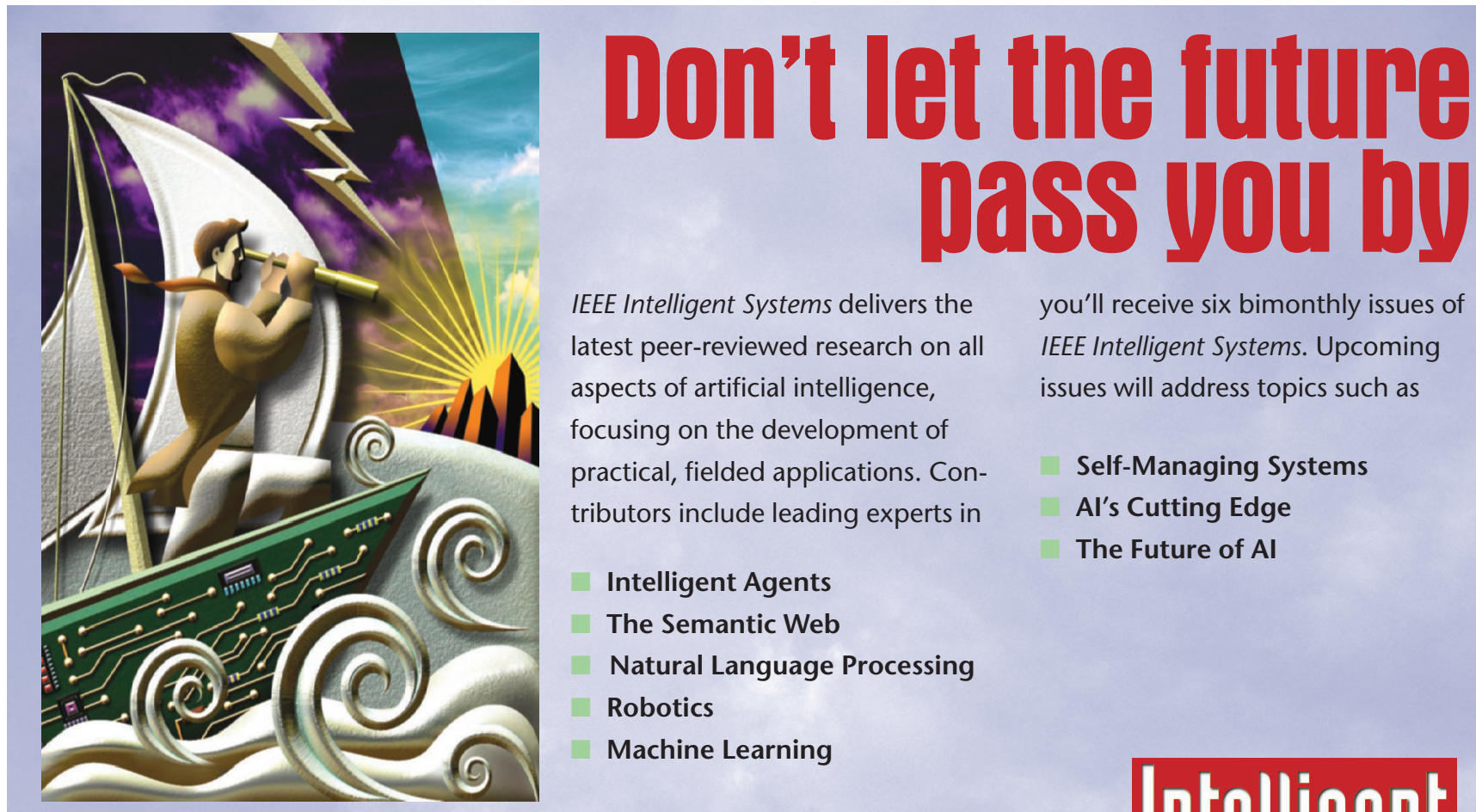

IEEE Intelligent Systems delivers the latest peer-reviewed research on all aspects of artificial intelligence, focusing on the development of practical, fielded applications. Contributors include leading experts in

\section{Intelligent Agents}

The Semantic Web

Natural Language Processing

Robotics

Machine Learning

For the low annual rate of $\$ 67$, you'll receive six bimonthly issues of IEEE Intelligent Systems. Upcoming issues will address topics such as

\section{Self-Managing Systems} Al's Cutting Edge The Future of Al

\section{Subscribe to IEEE Intelligent Systems}

